\title{
Post-Conflict Peace Building and Natural Resources
}

\author{
Carl Bruch, David Jensen, Mikiyasu Nakayama, Jon Unruh, \\ Rebecca Gruby, and Ross Wolfarth
}

\section{INTRODUCTION}

Natural resource management increasingly plays a pivotal role in the transition of post-conflict societies towards a lasting peace. This role is not limited to societies where conflict has been directly fueled by high-value natural resources such as timber or minerals. Unresolved issues surrounding land tenure administration can reignite tensions, and the inability of government to deliver key services (water, food, shelter, and other resourcedependent essentials for life) can destabilize weakened societies that are recovering from conflict. In addition to eliminating these potential obstacles to peace, good natural resource management can provide opportunities for confidence-building measures, serve as models of effective and equitable governance, and advance other peace-building objectives.

Since the Second World War, there have been more than 300 major armed conflicts around the world. ${ }^{1}$ The incidence of conflict has intensified in the years following the end of the Cold War:

The period since 1990 has been marked by a proliferation of violent conflicts, with nearly all of them located in the developing and transition countries, and many in the poorest countries. The character of these conflicts has been changing. While the incidence of interstate conflicts has not increased, the incidence of intrastate conflicts, including armed civil conflicts reached a peak in the early 1990s, with over one third of the world's countries affected by serious warfare at some point during the 1990s. ${ }^{2}$

As the vast majority of armed conflicts in the last sixty years have occurred in developing countries, most people directly affected by conflict live close

The authors gratefully acknowledge research assistance from Shakuntala Makhijani, Vivaan Nehru, and Samuel Shrank. Ken Conca, Lisa Goldman, Rene Nijenhuis, and Elissa Parker reviewed and commented on earlier drafts of this article. Any errors remain those of the authors.

1 See Major Episodes of Political Violence, 1947-2007, <http://www.systemicpeace.org/ warlist.htm>.

2 Caroline Bahnson and Jozefina Cutura, The Post Conflict Fund, Addressing Challenges of Globalization: An Independent Evaluation of the World Bank's Approach to Global Programs, Case Study, World Bank Operations Evaluation Department, at ix (2004), <http://lnweb18. worldbank.org/oed/oeddoclib.nsf/24cc3bblf94ae11c85256808006a0046/862c133dbb765db885 256f6500690879/\$FILE/gppp_pcf_wp.pdf>. 
to the land. Under such socio-economic conditions, the management of natural resources directly determines whether people will have land to grow food, timber and other resources for livelihoods, water for household consumption, and materials for shelter. These basic questions of survival have the power to ignite and reignite conflict. Conversely, perceived inequities in the distribution of revenue streams derived from natural resources can lead to strife. As such, it is no surprise that the United Nations Environment Programme (UNEP) has concluded that 'looking back over the past sixty years, at least forty percent of all intrastate conflicts can be associated with natural resources.'3

A wide range of natural resources can affect conflict and post-conflict resources. These include, for example, 'lootable' natural resources that can be easily collected on a small scale, such as alluvial diamonds, coltan, timber, or substances whose exploitation requires extensive mechanized infrastructure, such as oil or gas. One of the most common resources at issue is land, with concerns frequently revolving around land access, ownership, and reform. Natural resources also include agricultural products, ranging from conventional commodities such as cocoa, coffee, or bananas, to illicit substances such as coca or opium. Other natural resources that can play an important role in post-conflict peace building include water (for household consumption as well as for agriculture and rebuilding industry) and biodiversity (particularly as a means of generating revenue).

In recent decades, the United Nations has taken an increasingly active role in negotiating and keeping the global peace. Indeed, the Charter of the United Nations names as its foremost goal 'to save succeeding generations from the scourge of war, which twice in our lifetime has brought untold sorrow to mankind. ${ }^{4}$ In practice, however, a focus on ensuring the short-term peace generally takes priority over longer-term priorities that are necessary for creating conditions for a sustainable post-conflict peace. One of the primary challenges in post-conflict recovery and peace building is to shift the relevant time frame from the immediate future (securing food and water, preventing tensions from reigniting, and so on) to longer-term management. As such, post-conflict settings have often been characterized by significant environmental impacts by peacekeeping operations, refugee and displaced person camps, debris removal, and reconstruction efforts.

The growing experiences in peace building highlight the importance of natural resource management in the transition to peace. There is now ample evidence - largely ad hoc - of ways that natural resource management can help to maintain and strengthen peace, while the failure to manage natural resources

3 United Nations Environment Programme (UNEP), From Conflict to Peacebuilding: The Role of Natural Resources and the Environment, at 8 (2009).

${ }^{4}$ Charter of the United Nations (1945), <http://en.wikisource.org/wiki/Charter_of_the_ United_Nations $>$, preamble. 
appropriately can destabilize a fragile peace. Much of this experience centres around providing livelihood opportunities, as in many post-conflict countries agricultural land and other natural resources provide the primary source of income for the vast majority of the population. The link between post-conflict livelihoods and conflict recurrence has been well established:

$[\mathrm{U}]$ nemployment and economic stagnation are... powerful contributing factors to the reality that countries emerging from violent conflict face a 44 percent chance of relapsing into conflict in the first five years of peace. Consequently, the focus on livelihoods is key when building resilience to the threat of renewed violent conflict. ${ }^{5}$

The risk is even more critical in natural resource-related conflicts, which have been more than twice as likely to relapse as other conflicts since the Second World War. ${ }^{6}$ This increased likelihood of conflict relapse reflects the importance of natural resources in peace building as well as a history of underestimation and failure in post-conflict natural resource management. The opportunities presented by effective natural resource management for improving livelihoods are particularly important in post-conflict societies. Since the Second World War, new natural resource management regimes have been implemented during the peace process in only one-quarter of the post-conflict settings where the underlying conflict had a natural resource base. Even in those cases when a new resource-sharing mechanism has been put into place, conflict has been more likely to recur than in cases where no natural resource action is taken. ${ }^{7}$

Recent developments in the international peace-building community have sought to address natural resource and environmental issues. Intriguingly, some of these steps have been made by actors not generally focused on environmental issues, demonstrating the potential for peace building to serve as a pathway towards a deeper understanding of natural resources for actors beyond the environmental community. In 1997, the World Bank established the Post-Conflict Fund (PCF), a grant mechanism that provides financing for physical and social reconstruction activities in post-war societies. ${ }^{8}$ In addition to the PCF, the bank has formally recognized that land reform involving the redistribution of land is an effective means by which to address historical injustices resulting from the control of land and that future land investments would benefit from the definition and analysis

\footnotetext{
5 Piet Goovaerts et al., Demand-Driven Approaches to Livelihood Support in Post-War Contexts, International Labour Organization and World Bank, Social Development Papers, Paper no. 29, at 1 (2005), <http://siteresources.worldbank.org/INTCDD/214574-1107382173398/20877452/ WP29_Web.pdf>.

6 Helga Malmin Binningsbø and Siri Aas Rustad, Resource Conflicts, Resource Management and Post-Conflict Peace (2007), <http://www.allacademic.com//meta/p_mla_apa_research_ citation/1/7/8/6/5/pages178653/p178653-1.php>; and UNEP, supra note 3 at 11.

7 Binningsbø and Rustad, supra note 6 at 19.

8 Bahnson and Cutura, supra note 2 at vii.
} 
of proper investment practices in post-conflict situations. ${ }^{9}$ The Office of the United Nations High Commissioner for Refugees has developed and implemented guidelines to minimize the environmental impacts of its relief operations. ${ }^{10}$ The UN Department of Peacekeeping Operations and the Department of Field Support have been working with other UN agencies to develop environmental guidelines for peacekeeping. ${ }^{11}$

In 2005, the UN General Assembly established the UN Peacebuilding Commission to 'address the special needs of countries emerging from conflict towards recovery.' ${ }^{\text {' }}$ The commission has a mandate to address 'all that is needed to help a country move from war to peace, ${ }^{13}$ including the development of best practices for integrated strategies for post-conflict peace building and recovery. The commission has consulted with UNEP regarding how natural resource management can serve as a component of the transition from conflict to peace. The UN Food and Agriculture Organization (FAO), recognizing that the post-conflict administration of land 'can go directly to the matter of achieving sustainable peace,' has conducted case studies on post-conflict land administration ${ }^{14}$ and has developed general guidance for land managers. ${ }^{15}$

UNEP's Post-Conflict and Disaster Management Branch-and its predecessor the Post-Conflict Branch (PCoB) has perhaps gone furthest in integrating natural resources into post-conflict recovery and peace building. UNEP has conducted about eighteen post-conflict assessments of natural resource and environmental priorities and has facilitated subsequent efforts to address priorities identified in these assessments. ${ }^{16}$ In 2006, the PCoB started a process to develop methods for reviewing post-conflict natural resource management experiences to date and to draw on lessons learned.

9 Danielle Typinski, Investments in Land Administration, Policy and Markets, World Bank Group, Agricultural Investment Sourcebook, Module 10, <http://siteresources.worldbank. org/EXTAGISOU/Resources/Module10_Web.pdf>.

10 See UN High Commissioner for Refugees, Environmental Guidelines (2005), <http:// www.unhcr.org/cgi-bin/texis/vtx/protect/opendoc.pdf?tbl=PROTECTIONandid=3b03b2a04>.

11 See Birgitta Liljedahl et al., Environmental Impact Assessment in Peacekeeping Missions: Challenges and Opportunities, Swedish Defense Research Agency (2007), <http://www. foa.se/upload/projects/Africa/424-Liljedahl-Environmental-Impact-Assessment-in-peace. pdf>.

12 UN General Assembly (UNGA) Resolution 60/180 (2005), 'Peacebuilding Commission,' $<$ http://www.un.org/documents/resga.htm>

13 United Nations Peacebuilding Commission Questions and Answers, <http://www.un.org/ Pubs/chronicle/2006/issue1/0106p12.htm>.

${ }^{14}$ For discussions of case studies from Nicaragua, East Timor, Kosovo, Rwanda, and Cambodia, see D. Jon Unruh, Food and Agriculture Organization (FAO), Post-Conflict Land Tenure: Using a Sustainable Livelihoods Approach, LSP Working Paper no. 18 (2004), <ftp:// ftp.fao.org/docrep/fao/008/j5415e/j5415e00.pdf>.

15 FAO, Access to Rural Land and Land Administration after Violent Conflicts, Land Tenure Studies no. 8 (2005), <ftp://ftp.fao.org/docrep/fao/008/y9354e/y9354e00.pdf>.

16 See UNEP, Post-Conflict and Disaster Management Branch, "About," <http://postconflict. unep.ch/about.php?prog=andshow $=$ past $>$. 
This analysis responds to interest articulated by various UN agencies in improving peace building through the integration of environmental considerations. UNEP is addressing what it has identified as 'a lack of linkages' between institutions engaged in peace building and institutions engaged in environmental management at the local, regional, and national levels. ${ }^{17}$

While the peace-building community has yet to fully develop and implement these mechanisms for rationalizing and implementing post-conflict natural resource management, the work conducted by these and other groups provides a wealth of data concerning specific cases where natural resource management has and has not facilitated the transition to a lasting peace. Yet the process of taking stock of post-conflict natural resource experiences is still happening in an ad hoc manner, strewn across agencies and organizations. There has been no broad, overarching framework or dialogue within which to examine, compare, and contrast the experiences of various institutions in managing natural resources to facilitate the transition to peace in post-conflict societies. Individuals and groups may know how to handle specific issues, but the community as a whole is unaware of the full totality of lessons learned, possibly leading to the repetition of damaging mistakes. The Environmental Law Institute, UNEP, the University of Tokyo, and the Specialist Group on Armed Conflict and the Environment of the World Conservation Union's (IUCN) Commission on Environmental Law are partnering to foster such a dialogue. This effort seeks to examine experiences in post-conflict natural resource management, consider various approaches, and identify lessons learned, with the aim of informing and improving future post-conflict peace-building efforts. ${ }^{18}$

Taking stock of approaches and lessons learned is essential to improving post-conflict recovery and peace building by learning from past experiences in post-conflict natural resource management. In addition to improving peace building, it is important to better and more broadly understand the ways in which post-conflict natural resource management is different from peacetime natural resource management. The priorities are different from the peacetime objectives of sustainability (at least in the short term), the actors and funding are different, and on-the-ground capacity and context is different. In post-conflict regions, institutional capacity is devastated, there is often significant societal distrust, governmental authority is frequently non-existent, and political priorities are focused on recovery and the maintenance of peace. The approaches and principles that normally apply in sustainably managing natural resources frequently are infeasible-and may be

17 Patricia Kameri-Mbote, Conflict and Cooperation: Making the Case for Environmental Pathways to Peacebuilding in the Great Lakes Region, Woodrow Wilson Center Environmental Change and Security Program Special Report, Issue 11 (2006), <http://www.wilsoncenter.org/ topics/pubs/KameriMbote12.pdf $>$.

18 For more information on this project, see $<\mathrm{http}$ ://www.eli.org/Program_Areas/PCNRM/>. 
inappropriate - in a post-conflict setting. This is not to say that sustainability is irrelevant; only that expedited processes may be necessary, for example, for environmental impact assessment. At times, the temporary unsustainable exploitation of a resource may even be necessary in order to facilitate the transition to a sustainable peace.

\section{PAST EXPERIENCES}

Natural resource management can be, and has been, a part of most (if not all) components of post-conflict peace building and recovery. Natural resources can be incorporated into the peace negotiation process as 'deal sweeteners' in peace settlement agreements and as confidence-building measures. Natural resource management can play an even greater role in the subsequent transition to peace. The components of such management for peace: preventing a return to conflict, meeting the basic needs for life (water, food, shelter, and livelihoods), decommissioning armed forces, and strengthening governance and justice all provide opportunities for natural resource management to improve post-conflict conditions.

1. Negotiating for Peace

\section{A. Peace Settlement Agreements}

Peace settlement agreements often explicitly grant certain parties access to, or control over, lucrative natural resources (such as timber or mineral rights) as immediate incentives for peace. This is logical, as much of the wealth and economic potential in recent post-conflict countries is associated with natural resources. Ministries with natural resource authority are also often distributed between conflicting parties as incentives. Unfortunately old animosities frequently persist, and cooperation among ministries that are led by former enemies - particularly between those led by individuals who were former combatants - often becomes problematic. For example, the Angolan government retained control of some ministries while allocating others to former rebels of the National Union for the Total Independence of Angola (UNITA), making ongoing institutional coordination difficult, for instance with water management and agriculture. ${ }^{19}$

However, peace settlement agreements also present opportunities to address long-standing grievances over natural resources. In Nepal-where only 20 percent of the nation's land is suitable for the agriculture on which 78 percent of the population relies for subsistence-land and land tenure were important issues during the peace negotiations. Section 3.7 of the

19 Lusaka Protocol, Annex 6 (1994), <http://www.c-r.org/our-work/accord/angola/lusakaprotocol.php>. 
Comprehensive Peace Agreement between the Government of Nepal and the Communist Party of Nepal (Maoist) directs both parties to resolve existing conflict in the country by 'adopt[ing] the policy to implement a scientific land reform program by ending the feudalistic system of land holding. ${ }^{20}$ This provision seeks to address the grievances of many Nepali people generated by the inequitable distribution of land. For instance, the bottom 47 percent of the population own 15 percent of arable land, whereas the top 5 percent own 37 percent, and 29 percent of the population are landless and more than 70 percent of peasants own less than one hectare of arable land. ${ }^{21}$ The agreement also requires the adoption of a 'policy to provide land and other economic protection to landless squatters. ${ }^{22}$ The framework for improving land tenure and management provided by these two measures is designed to help resolve a long-standing source of conflict as well as to provide livelihood opportunities for former combatants. ${ }^{23}$

Despite these cases, it is significant that relatively few peace agreements to date have addressed natural resources. Since the Second World War, UNEP estimates that 'fewer than a quarter of peace negotiations aiming to resolve conflicts linked to natural resources have addressed resource management mechanisms. ${ }^{24}$ One possible explanation for this failure is that natural resources, and especially land, can easily become a 'sticking point' in negotiations due to their paramount economic and social importance. Consequently, negotiators may avoid addressing such sensitive issues in order to more quickly stop the violence, with the ironic result that the flawed peace agreements may contribute to the high recurrence rates of conflicts linked with natural resource. ${ }^{25}$

\section{B. Confidence-Building Measures}

In addition to distributing natural resources-or the authority over the governance of natural resources - as incentives for peace, peace agreements can mandate or encourage the collaborative management of natural and environmental resources. Such efforts can build confidence between former combatants. In 1998, after intense negotiation and international intervention, Peru and Ecuador signed the Acta Presidencial de Brasilia, ending

\footnotetext{
${ }^{20}$ Comprehensive Peace Agreement between the Government of Nepal and the Communist Party of Nepal (Maoist), para. 3.7 (2006), <http://www.reliefweb.int/rw/RWB.NSF/db900SID/ VBOL-6VSHK8?OpenDocument> [Comprehensive Peace Agreement].

21 Richard Matthew and Bishnu Raj Upreti, Environmental Stress and Demographic Change in Nepal: Underlying Conditions Contributing to a Decade of Insurgency, Woodrow Wilson Center Environmental Change and Security Program Special Report, Issue 11, at 36-7 (2005), $<$ http://www.wilsoncenter.org/topics/pubs/Nepal_Env_StressandDemo_Change.pdf $>$.

22 Comprehensive Peace Agreement, supra note 20 at para 3.10.

23 Matthew and Upreti, supra note 21 at $37 . \quad 24$ UNEP, supra note 3 at 19.

25 See Binningsbø and Rustad, supra note 6 and accompanying text.
} 
nearly six decades of territorial border conflict in the Cordillera del Cóndor mountain range. ${ }^{26}$ In order to promote bilateral cooperation, the peace agreement officially established adjacent zones of ecological protection, or 'peace parks,' on both sides of the Peru-Ecuador border. These parks were to be managed by the respective national protected-area agencies with support from a bi-national steering committee. The parks, including the 2,540-hectare El Cóndor Park in Ecuador and the 5,440-hectare Ecological Protection Area in Peru, serve to consolidate the peace process between Peru and Ecuador by fostering effective transboundary coordination and cooperation in the management of protected areas. ${ }^{27}$ This shared responsibility has spurred further formal collaboration in the post-conflict period. In 1999, Peru's National Institute of Natural Resources and Ecuador's Ministry of Environment signed a separate agreement to foster bilateral cooperation through environmental management, sustainable development, and conservation initiatives. The transboundary management of environmental resources has improved relations between Peru and Ecuador as well as security in the Cordillera del Cóndor mountain range, and the "Border Protected Areas act as real "links" connecting peace and conservation... [that] have helped create an environment for long-lasting peace in the region. ${ }^{28}$

Confidence can also be built through the shared management of resources necessary for survival. Since water issues play a central role in the broader political conflict between Israel and its neighbours in the Jordan River basin, the inclusion of water management provisions in the 1994 peace treaty ${ }^{29}$ 'was essential for Jordan and Israel and Israel and the Palestinian Authority to reach an agreement. ${ }^{30}$ The treaty called for the construction of a desalination plant in Aqaba, Jordan, and the supply to Jordan of fifty million cubic meters of potable water per year from the river. ${ }^{31}$ More broadly, the 1994 treaty recognized 'the importance of the ecology of the region, its high environmental sensitivity and the need to protect the environment and prevent danger and

26 Acta Presidencial de Brasilia (1998), <http://www.cipca.org.pe/cipca/frontera/acuerdos/ PER150.htm>.

27 Carlos F. Ponce and Fernando Ghersi, Cordillera del Condor (Peru-Ecuador), paper prepared for the Workshop on Transboundary Protected Areas in the Governance Stream of the Fifth World Parks Congress, at 2 (September 2003), <http://www.tbpa.net/docs/ WPCGovernance/CarlosPonceFernandoGhersi.pdf $>$.

28 Martín Alcalde et al., Peace Parks in the Cordillera del Cóndor Mountain Range and Biodiversity Conservation Corridor, Woodrow Wilson Center for International Scholars (draft paper), at 6, <http://www.wilsoncenter.org/events/docs/ponce.pdf> (viewed 13 Feb. 2009).

29 Treaty of Peace between the State of Israel and the Hashemite Kingdom of Jordan (1994), Annex IV Environment (25 August 1999), <http://www.mfa.gov.il/MFA/Peace\%20Process/ Guide $\% 20$ to $_{0}$ 20the $\% 20$ Peace $\% 20$ Process/Israel-Jordan $\% 20$ Peace $\% 20$ Treaty $\% 20$ Annex $\% 20$ IV> (viewed 13 Feb. 2009).

30 Erika Weinthal, Harnessing the Environment in Post-conflict Peacebuilding, paper presented at the Forty-Seventh Annual Convention of the International Studies Association (March 2006). 
risks for the health and well-being of the region's population.' The parties agreed to 'co-operate in matters relating to environmental protection in general and to those that may mutually affect them. ${ }^{32}$ This agreement has helped Israel and Jordan to focus on the shared management of their common natural resources in order to build trust, confidence, and cooperation between the nations. It also highlights the fact that effective natural resource management may help to transition to peace, but it will not guarantee peace.

Even when formal negotiating channels are closed or have stagnated, natural resource-based confidence building can occur through informal means. For example, collaboration among non-diplomats through unofficial channels has yielded promising results for the riparian states of the Euphrates-Tigris River basin. The official diplomatic channel of negotiation between these nations - the Joint Technical Committee, which comprises diplomats from Iraq, Syria, and Turkey - has not been functional for more than a decade. Nevertheless, dialogues led by the Euphrates-Tigris Initiative for Cooperation and Kent State University have promoted conversation and cooperation among government officials, experts, and researchers from these riparian countries. ${ }^{33}$ Informal natural resource dialogue has laid the foundation for more fruitful formal diplomatic discussions in the Euphrates-Tigris River basin, as evidenced by Iraq's recent shift to a more engaged and constructive diplomatic posture.

As these examples suggest, confidence building through natural resource management may play a prominent, but imperfect role in the aftermath of interstate conflicts. In such cases, the management of shared natural resources, such as rivers and transboundary protected areas, can provide an avenue for technical cooperation and confidence building, even when political discourse is highly contentious. The necessity of cooperating in managing certain resources can foster and support a process of constructive engagement that would be less likely to emerge where cooperation and dialogue could be avoided. Yet, as noted earlier, despite the importance of natural resources in post-conflict peace building, natural resources often are not addressed when negotiating for peace. This failure to consistently and effectively address natural resources in peace agreements may undermine the long-term peace, contributing to the higher likelihood of relapse to conflict where there is a link to natural resources.

\section{Transition to Peace}

While the incorporation of natural resources into peace agreements is an important step, the operational processes for transitioning to peace invariably address natural resources in ways that are not explicitly addressed or

\footnotetext{
32 Ibid.

33 Information included in this paragraph is drawn from the experiences of two of the authors who participated in the initiative.
} 
anticipated in the formal agreement. Natural resource management is often an important means for realizing measures to avoid a return to conflict, to meet the basic needs of life (water, food, shelter, and livelihoods), to rebuild the economy, to decommission armed forces, and to strengthen governance while addressing past injustices. ${ }^{34}$ Failure to effectively manage any of these processes can destabilize a country and lead to renewed hostilities.

Different organizations are involved in different aspects of the postconflict transition to peace. Such institutions include the UN Department of Peacekeeping Operations, which keeps the peace and seeks to prevent a relapse into conflict; the UN High Commissioner for Refugees, the International Committee of the Red Cross, and private relief organizations, which provide food, shelter, water, fuel, and medical care; truth and reconciliation commissions, international tribunals, and bilateral assistance, which often are responsible for assisting countries in addressing past injustices; and the UN Development Program and other institutions seek to strengthen governance. In practice, communication between these operations is sporadic and limited, especially across sectors. The sound management of natural resources cuts across operational divisions and provides an opportunity to encourage dialogue and collaboration. As such, sound natural resource management can become more than an element, or even a prerequisite, for the achievement of peace. It has the potential to become a means and a context for operationalizing peace-building objectives on a structural level.

\section{A. Preventing a Return to Conflict}

Reforms in natural resource management following the cessation of hostilities can help to reduce societal tensions and reduce the likelihood that conflict will recur. This is particularly true when the conflict arises from disputes over natural resources or is fuelled by natural resources. ${ }^{35}$ The experience of postconflict Liberia illustrates how effective natural resource management can reduce conflict recurrence. According to the United Nations, "poor management and overexploitation of Liberia's natural resources... created and fuelled civil war and conflict' for fourteen years. ${ }^{36}$ Timber and diamonds were illegally harvested for trade in international markets to finance armed rebel movements and their allies. ${ }^{37}$ Simultaneously, government corruption and inattention

${ }^{34}$ See UNEP, supra note 3.

35 See, e.g., US Agency for International Development (USAID), Forests and Conflict: A Toolkit for Programming (2005), <http://www.usaid.gov/our_work/cross-cutting_programs/ conflict/publications/docs/CMM_Forests_and_Conflict_2005.pdf>.

${ }^{6}$ United Nations Environment Programme, Desk Study on the Environment in Liberia, at 8 (2004), <http://postconflict.unep.ch/publications/Liberia_DS.pdf>.

${ }^{37}$ See, among others, Global Witness, Timber, Taylor, Soldier, Spy: How Liberia's Uncontrolled Resource Exploitation, Charles Taylor's Manipulation and the Re-recruitment of 
to community needs in the forestry sector were so severe that 'Liberia had approximately $60,000 \mathrm{~km}^{2}$ of forestry concessions in 2002, covering $133 \%$ of Liberia's forests,' meaning that many 'rural settlements, and associated sacred groves, burial grounds, etc., were entirely within logging concessions. ${ }^{38}$ As a result of the role that timber and diamonds played in Liberia's civil war, the United Nations Security Council imposed bans on trade in so-called 'blood diamonds ${ }^{39}$ and "blood timber. ${ }^{20}$ Following a change of government and the reform of the timber sector, the bans were lifted in 2006. ${ }^{41}$

Embedded in the 2003 Accra Peace Agreement, the notion of reforming the country's natural resource management emerged as a central means of preventing a return to conflict. ${ }^{42}$ The new government of Liberia and the United Nations placed a priority on establishing a strong, effective, and sustainable legislative and institutional framework to manage the resources whose theft and abuse had for so long provided the engine of war. In her first executive orderExecutive Order no. 1-Liberian president Ellen Johnson-Sirleaf cancelled all existing timber concessions in Liberia in early 2006. In the order, the president charged that 'the natural resources sector over the last two decades has been characterized by lack of: transparency, accountability, civil society participation (especially by non-governmental organizations and rural people), and equitable sharing of benefits by the industry. ${ }^{93}$ This order laid the groundwork for subsequent reforms to improve the governance of the timber sector, removing a source of conflict as well as a means of financing conflict. Motivation for the reform of the timber sector was provided in part by UN Security Council Resolution 1521, which banned the export of round logs and timber products.

In Sierra Leone, the United Nations, bilateral agencies, and private organizations are assisting the government in reforming the diamond trade, which, in large part, fuelled this country's eight-year civil war. ${ }^{44}$ An increasing

Ex-combatants Are Threatening Regional Peace (June 2005), <http://www.globalwitness.org/ media_library_detail.php/137/en/timber_taylor_soldier_spy>; and UNEP, Environmental Considerations of Human Displacement in Liberia: A Guide for Decision-makers and Practitioners, (2006), <http://postconflict.unep.ch/publications/UNEP_HR.pdf>.

38 Jamison Suter, Forest Conservation and Management in Liberia: Piloting Communal Forests in the Post-Conflict Period, Liberia Forest Initiative (2004), <http://www.fao.org/ forestry/29660/en/>.

39 UN Security Council (UNSC) Resolution 1343 (2001). UNSC resolutions can be accessed at <http://www.un.org/documents/scres.htm>.

40 UN Security Council Resolution 1521 (2003).

41 UN Security Council Resolution 1689 (2006).

42 Comprehensive Peace Agreement Between the Government of Liberia and the Liberians United for Reconciliation and Democracy (LURD) and the Movement for Democracy in Liberia (MODEL) and Political Parties (2003), <http://www.iss.co.za/Af/RegOrg/unity_to_ union/pdfs/ecowas/liberiapeace.pdf $>$.

43 Liberia: Forest Sector Reform, Executive Order no. 1 (2006), <http://www.elaw.org/ node/2028>.

44 USAID, Economic Governance in War Torn Economies: Lessons Learned from the Marshall Plan to the Reconstruction of Iraq (2006), <http://www.oecd.org/dataoecd/17/43/36144028.pdf>. 
number of diamond traders are formally licensed by the government, with their activities monitored to ensure legal trade. As a result of these efforts, the extent to which conflict diamonds are funding arms purchases in Sierra Leone 'has been greatly reduced,' while the contribution of diamond revenues to state revenue has increased substantially. ${ }^{45}$

An obvious target for the replication of the approaches that have had success in Liberia and Sierra Leone is nearby Côte d'Ivoire, which is recovering from civil conflict. Côte d'Ivoire is the world's largest producer of cocoa, and the cocoa industry has been 'at the heart of the war economy and continues to serve the interests of protagonists to the conflict. ${ }^{96}$ Côte d'Ivoire's cocoa institutions

have directly contributed to the war effort by providing the government with money [(US \$20.3 million)], vehicles and weapons, using money from cocoa levies... an obvious deviation from the cocoa institutions' official role, which is to regulate the cocoa trade and support cocoa farmers. Today, profits from the sector remain a potential 'weapon of war' and little has been done to break the links between the cocoa trade and the armed conflict. 47

Unfortunately, peace talks and agreements in Côte d'Ivoire have thus far not addressed the lack of accountability and transparency in the trade of the country's most lucrative resource. It is uncertain whether Côte d'Ivoire can achieve long-term peace without resolving these issues.

Natural resource management can deter the re-emergence of interstate warfare as well, as in the case of the European Coal and Steal Community (ECSC) created in 1952. According to the primary architect of the plan, Jean Monnet, the foremost goal of the community was to 'exorcise history' by annihilating the ancient enmity of France and Germany through the shared management of natural resources. ${ }^{48}$ The ECSC placed French, German, Italian, and Benelux (Belgium-Netherlands-Luxemburg) production of coal under a common high authority so as to

change the destinies of those regions which have long been devoted to the manufacture of munitions of war, of which they have been the most constant victims. The solidarity in production thus established will make it plain that any war between France and Germany becomes not merely unthinkable, but materially impossible. ${ }^{49}$

\footnotetext{
45 Ibid.

46 Global Witness, Hot Chocolate: How Cocoa Fuelled the Conflict in Cote d'Ivoire, at 59 (2007), <http://www.globalwitness.org/media_library_detail.php/552/en/hot_chocolate_how _cocoa_fuelled_the_conflict_in_co $\% 20 \mathrm{at} \% 203>$. $\quad 47$ Ibid. at 24.

48 Nicolaus Mills, Winning the Peace: The Marshall Plan and America's Coming of Age as a Superpower, at 187 (1995).

49 Schumann Declaration (May 1950), <http://www.ena.lu/schuman-declaration-
} paris-1950-020000152.html>. 
The strategy of coordinated, international management of natural resource and economic integration initiated by the ECSC was pivotal in transforming western Europe from the generator of world wars to a notably peaceful area of the world. The ECSC directly provided the basis for more extensive regional cooperation, eventually transforming into the European Union (EU). Intriguingly, over the past decade, the EU has used the promise of future EU membership as a key component of post-conflict activities in the Balkans. These efforts have included the creation of the Energy Community of Southeast Europe, a regional organization that is 'basically built along the lines of the Coal and Steel community. ${ }^{50}$ Thus, a powerful regional organization with its origins in post-conflict natural resource management (the EU) is using natural resource management to maintain peace in another region (southeast Europe). Similar rhetoric based on the ECSC as well as the Marshall Plan that coordinated the rebuilding of Europe after the Second World War-of a regional approach to cooperation, management of natural resources, and economic integration - is currently being invoked as a potential solution for post-conflict recovery and peace building in other countries, such as Haiti, Afghanistan, and Iraq. ${ }^{51}$

\section{B. Fulfilling Essential Human Needs}

Meeting the basic needs of refugees, internally displaced persons (IDPs), and other people in post-conflict countries depends upon the maintenance of an intact and accessible resource base. ${ }^{52}$ In the chaos and devastation following conflict, it can be a daunting task to provide adequate food, clean water, shelter, and energy - let alone jobs - to thousands (or even hundreds of thousands) of people traumatized by conflict. Yet, failing to address essential human needs can quickly destabilize post-conflict societies.

The appropriate management of natural resources is critical to meeting many of these needs. Most recent wars have been in countries whose people and economies have depended on agriculture for 'livelihoods, foreign exchange, and social stability. ${ }^{53}$ An International Labour Organization and

50 Erhard Busek, South-east Europe on the Way to Euro-Atlantic Integration, in Klaus Liebscher, ed., European Economic Integration and South-east Europe: Challenges and Prospects, 30 at $36(2005)$.

51 Pavel Novacek et al., Marshall Plan for Haiti: Initial Project of the Global Partnership for Development 9(1) Foresight 59 (2007); Asif Ghani, Afghanistan Is a Failing State, It Needs a Marshall Plan, The Guardian, 29 December 2008; Ibrahim Al-Jaafari, A New Marshall Plan for Iraq, London Times, 27 June 2005.

52 Ken Conca and Jennifer Wallace, Environmental Peacebuilding in War-Torn Societies: Lessons from the UN Environment Programme's Experience with Postconflict Assessment, Global Governance (forthcoming 2009).

53 Nikki Skuce, Human Security and Agriculture: A Case Study of the One Sky/Friends of the Earth Sierra Leone Partnership Project, One Sky, <http://www.onesky.ca/files/uploads/ OneSky_Agcase_study.pdf $>$. 
World Bank study identifying the appropriate areas to target for economic revival emphasizes natural resources:

Economic sectors should be targeted that are essential to postwar recovery, have multiplier effects that may affect the economy as a whole and are likely to attract donor and governmental funds. For these reasons, agriculture/fishing and construction, as well as the support industries, services and trade networks related to these two sectors, are generally the most opportune for post-war economic recovery. In rural areas, agriculture, fishing and related food processing and marketing activities often capitalize on pre-war skills, and can help enhance food security and mitigate 'shocks' once food relief is discontinued. Reconstructing war damaged or dilapidated infrastructure is also of high priority in order to lay the groundwork for potential economic growth, and often has the benefit of availability of donor and government funds. These sectors bear the added advantage of generally being suitable for low-skilled labor and on-the-job training activities. ${ }^{54}$

In some countries, the natural resource bias is even more pronounced-in Afghanistan, 'more than 80 percent of the population relies directly on natural resources such as rangelands and water bodies for their livelihood and daily needs. ${ }^{55}$ Reintegrating former combatants into a nonindustrial society generally entails making land accessible for ex-combatants, as agriculture often represents one of the few viable alternatives to soldiering.

The desperation and frustration stemming from limited access to natural resources following conflict has the real potential to foment unrest and undermines the viability of a long-term peace. In Nepal, IUCN conducted in-depth interviews with representatives from 19 ethnic groups whose livelihoods rely on the natural resources of the Koshi Tappua region. The study found that the villagers'

traditional or customary rights to local natural resources have been curtailed or denied. Consequently, their livelihoods have become increasingly perilous, and their willingness to engage in protest and crime has increased. ${ }^{56}$

This lack of a stable source of livelihood for Nepal's burgeoning population of poor and landless villagers in the region made them more receptive to recruitment by Maoist rebels and continues to present challenges for long-term peace.

Iraq's Mesopotamian marshlands exemplify the potentially vast scope of environmental and natural resource damage that post-conflict countries can inherit as well as the deleterious effects on the fulfillment of human needs. The marshlands have supported a unique subsistence lifestyle for the Marsh Arabs for over five millennia. However, in the early 1990s, in retribution for

54 Goovaerts et al., supra note 5 at 17.

55 David Taylor, New Environmental Law for Afghanistan 114(3) Envt'l Health Perspectives A152 (2006), <http://www.pubmedcentral.nih.gov/articlerender.fcgi?artid=1392251>.

56 Matthew and Upreti, supra note 21 at 37. 
the insurrection delivered by the Marsh Arabs, Saddam Hussein's regime drained 90 percent of the marshlands, devastating the local communities and their way of life. In addition to this systematic destruction by the Iraqi government, the marshes became a central battlefield for the war that engulfed southern Iraq in 1991-3. Marsh villages were attacked and burned down, and the waters around the villages were poisoned with chemicals and ultimately diverted. Between 350,000 and 500,000 Marsh Arabs were displaced as environmental refugees. With the disappearance of the marshlands, 'the social and economic livelihood of the Marsh Arabs has fallen apart. ${ }^{57}$

In addition to supplying the livelihoods of hundreds of thousands of Marsh Arabs in Iraq, the degraded marshlands are integral to the health of the waterways that constitute the country's main water supply. ${ }^{58}$ The loss of the Mesopotamian marshlands must be seen in a broad regional and global context of growing water stress. UNEP has noted that if not resolved, 'this water crisis poses a potential threat to regional security with grave consequences to the basin's inhabitants and their environment that will only become fully manifest in future decades. ${ }^{59}$ A number of groups working in post-conflict Iraq have recognized the symbolic and practical benefits of marshland recovery. Japan contributed US \$11 million to a trust fund that is dedicated to marshland restoration projects, proclaiming that 'the trade, agriculture and fishing opportunities created by the restored marshes could become a beacon of hope for the rest of Iraq, helping to stabilise both the region and the country's wider economy. ${ }^{90}$ Administered by UNEP's International Environment Technology Center, these projects are expected to provide marshland returnees with clean water and sanitation facilities. Agencies from Canada and the United States are also funding marshland rehabilitation projects. ${ }^{61}$

These projects have provided assistance to the local population using a variety of approaches, including strategic development and coordination, data collection and baseline analysis, capacity building, pilot implementation, awareness-raising, and follow-up activities. ${ }^{62}$ Such projects augment the capacity of Iraqi decision makers and community representatives on policy and institutional matters, technical subjects, and analysis. For example,

57 Hassan Partow, The Mesopotamian Marshlands: Demise of an Ecosystem, Early Warning and Assessment Technical Report, Doc. UNEP/DEWA/TR.01-3 Rev. 1, UNEP Division of Early Warning and Assessment, at 34 (2001), <http://www.grid.unep.ch/activities/sustainable/ tigris/mesopotamia.pdf $>$.

58 Bryant Furlow, A Struggle for Eden: Iraq Faces an Uncertain Future. But Restoring the Country's Great Marshlands Could Bring Hope and Stability to Its People (Special Report Reconstructing Iraq), No. 178.2392 New Scientist 14 (2003).

59 Partow, supra note 57 at $1 . \quad 60$ Furlow, supra note 58.

61 Japanese Ministry of the Environment, Current Status of Iraq's Environment and Ongoing Reconstruction Initiatives, at 26, <http://www.env.go.jp/earth/report/h18-02/e008.pdf >.

62 Support for Environmental Management of the Iraqi Marshlands UNEP website, $<$ http:// marshlands.unep.or.jp/default.asp?site $=$ marshlandsandpage_id=7B495B9E-13E0 $-4 \mathrm{DFE}$ 9D1D-C77580754FB4>. 
a web-based Marshland Information Network is being developed to provide a forum for stakeholders to share information, establish a clearing house for information on technical management and assessments, and facilitate the development of shared strategies and partnerships among stakeholders. ${ }^{63}$ This technical assistance supplements on-the-ground projects to deliver water, rebuild communities, and foster livelihoods.

In the same way that environmental destruction was used by Saddam Hussein's regime to persecute the marshland residents, the recovery of the marshlands is viewed by many Iraqis as a crucial symbolic 'act of peace. ${ }^{64}$ Such restoration can serve as a 'peace dividend'-along with the development of livelihood opportunities, delivery of basic services, and improving governance and the rule of law-helping to convince people that the maintenance of peace is in their best interest. There are numerous and diverse ways in which natural resource management can support efforts to meet the essential needs of post-conflict populations. The following sections describe a few specific areas where natural resources can support-or otherwise affect - post-conflict efforts to meet basic needs.

\section{(i) Land tenure}

Unresolved land and property issues in post-conflict settings pose a particular threat of sparking renewed conflict driven by unmet human needs. This risk is amplified after prolonged conflicts, which often create a situation in which many people can assert more or less legitimate claims to land and land-based resources in the absence of reliable records or a history of longterm land stability. ${ }^{65}$ Resolving these issues in a prompt and comprehensive fashion is necessary to ensure the continued viability of the peace process. ${ }^{66}$ The development and implementation of effective property rights systems can resolve disputes, remove a potential flashpoint for conflict, and provide broad access to land for livelihoods and cultural identity. ${ }^{67}$

However, land reform can be extremely challenging. Establishing or adjusting rights to own and use land is politically charged even during peacetime and can become considerably more difficult in post-conflict contexts. Local and national governments have limited capacity, records frequently are destroyed or in disarray, and different people and ethnic groups often

\footnotetext{
63 Ibid.

64 Personal communication with Chizuru Aoki, UNEP International Environmental Technology Centre (7 May 2007).

65 D. Jon Unruh, Land and Property Rights in the Peace Process, in Guy Burgess and Heidi Burgess, eds., Beyond Intractability, Conflict Research Consortium (2004), <http://www. beyondintractability.org/essay/Land_tenure/>. 66 Ibid.

67 Nicolas Pons-Vignon and Henri-Bernard Solignac Lecomte, Land, Violent Conflict and Development, OECD Development Center, Working Paper no. 233 (2003), <http://lysander. sourceoecd.org/vl=5879939/cl=15/nw=1/rpsv/cgi-bin/wppdf?file=51gsjhvj770w.pdf $>$.
} 
have competing claims and unresolved grievances. ${ }^{68}$ The return of refugees and IDPs provides another level of complication, further expanding the potential for conflict. Yet, however difficult the process, addressing questions of land tenure in post-conflict societies can be a precondition to the establishment of lasting peace and order. ${ }^{69}$ Indeed, if handled properly, 'land policy may play a crucial, "positive role" within strategies aimed at consolidating peace in areas emerging from conflict. ${ }^{70}$

The importance and challenge of addressing land tenure is a recurrent theme in post-conflict recovery and peace building. Following the end of Mozambique's civil war in 1992, the inability to resolve land disputes hindered the peace process. ${ }^{71}$ In Nicaragua, misunderstandings surrounding access to land led the Contras to re-arm themselves during the peace process. ${ }^{72}$ In El Salvador, ambiguity in the peace accord with respect to land tenure led to serious stumbling blocks in its implementation, and the land issue ultimately became the final sticking point in El Salvador's peace process, stalling complete demobilization. ${ }^{73}$ As civil conflict grew in Somalia in the early 1990s, competing claims for land rights were asserted by nomadic pastoralists, small-scale agriculturalists, large-scale landowners, and heavily armed clans seeking to control these rights.

The lack of a functioning system for land registration in rural Afghanistan has contributed to numerous disputes over land among the some three million IDPs who have returned since 2001. There is a direct causal chain linking poor tenure security and obfuscated land rights to broader insecurity for the tenuous peace in Afghanistan:

- a weak tenure system, in which people have no stake in land, begets poor management and resource degradation;

- land degradation, and its subsequent decreased productive potential, increases livelihood insecurity; and

- livelihood insecurity contributes significantly to overall social and civil instability. ${ }^{74}$

Experts assisting Afghanistan in post-conflict reconstruction have argued that stability and security cannot be achieved unless and until an effective

68 Ibid.

${ }^{69}$ Liz Alden Wily, Land Rights in Crisis: Restoring Tenure Security in Afghanistan, Afghanistan Research and Evaluation, Issue Paper Series, at 5 (March 2003), <http://unpan1. un.org/intradoc/groups/public/documents/APCITY/UNPAN016656.pdf>.

70 Pons-Vignon and Lecomte, supra note 67 at 12.

71 D. Jon Unruh, Local Land Tenure in the Peace Process 14(3) Peace Review 337-42 (2002).

72 Ibid. $\quad 73$ Ibid.

74 Alec McEwen and Sharna Nolan, Water Management, Livestock and the Opium Economy: Options for Land Registration, Afghanistan Research and Evaluation Unit, Working Paper Series (2007), <http://www.areu.org.af/index.php?option=com_docmanandtask=doc_detailsandgid $=475$ andItemid $=26>$. 
and equitable system of land administration is implemented. ${ }^{75}$ In agrarian societies such as Afghanistan,

production and livelihood, economic growth and social stability depend heavily upon orderly and accepted land access and ownership systems. When the way in which land rights are ordered is contested, peace and security are difficult to attain or sustain. ${ }^{76}$

Several efforts to construct an effective system of land administration-and thereby lay the foundation for a durable peace-are currently under way. Land registration benchmarks were included in the interim Afghanistan National Development Strategy, and in January 2007 a new draft land policy was approved by the Afghanistan National Development Strategy Land Policy Working Group for submission to the Cabinet. ${ }^{77}$ This policy establishes principles and targets for the governance of land and rights of tenure. The European Commission supported these endeavours by providing funding that will enable the Afghanistan Research and Evaluation Unit to create a strategy for land registration for rural Afghanistan and to develop mechanisms for its adoption and implementation. ${ }^{78}$

In the absence of legitimate, peaceful means to resolve disputes over land, post-conflict land problems can compel dislocated individuals to challenge post-war authority structures and sources of legitimacy - two of the biggest obstacles in peace processes. ${ }^{79}$ Experiences in Sierra Leone, East Timor, and Cambodia illustrate how quickly addressing these land tenure issues can facilitate the transition to peace. At the end of the civil war, hundreds of thousands of refugees returned to Sierra Leone, many of them former farmers. However, much of the land in rural Sierra Leone was held by extended families or lineages that were reluctant to allow the returning refugees access to their land-even on a temporary basis and despite the fact that the lineages often lacked the manpower to keep the land in production-out of fear that the newly empowered lessees might attempt to subsequently claim full ownership rights to the land through adverse possession. As acres of fertile land remained fallow, IDPs and refugees lacked the means for livelihoods, and food security and the stability of the fragile peace grew tenuous. Rather than undertaking a lengthy process of general land tenure reform, the government amended the law to explicitly guarantee the right of reversion to landowning families. This law thereby granted the tenure security that the landowners required and facilitated the temporary settlement and

\footnotetext{
75 Wily, supra note 69 at $5 . \quad 76$ Ibid. at 11.

77 Land Policy, adopted on 3 September $2007<$ http://www.ltera.org/index.php?option=com docman\&task=doc_download\&gid=80\&Itemid=63 $>$ (final draft adopted by the Cabinet of Ministers).

78 McEwen and Nolan, supra note 74 at $6 . \quad 79$ Ibid.
} 
agricultural activity of returning refugees. ${ }^{80}$ By addressing the landowners' specific concerns in a timely manner, the government was able to improve food security and social stability at a critical juncture in the long, slow road to peace. It also bought time for the government to begin a consultative process for land reform rather than rushing through the process.

In East Timor, conflicts following independence from Indonesia in 1999 resulted in the displacement of 75 percent of the population, the destruction of 70 percent of physical infrastructure, and widespread abandonment and destruction of property and official records. ${ }^{81}$ Emergent political groups in postconflict East Timor - largely veterans of the twenty-five-year insurgency - who felt 'left out of the benefits of peace, including access to land, ${ }^{82}$ fomented unrest, accusing the government of inaction on land issues and igniting numerous violent conflicts. Recognizing the need to address land problems expeditiously, the government of East Timor promulgated new property rights laws. The government conducted significant research into customary land tenure and mediation efforts that 'were effective at mitigating disputes and their effects so that peace, farming, and recovery continued' and incorporated them into the reforms. ${ }^{83}$

The Cambodian experience can be seen as 'a cautious success story' concerning the power of land tenure reform to foster reconciliation, even after protracted conflicts. ${ }^{84}$ In 1975, the post-colonial revolution by the Khmer Rouge in Cambodia instituted unprecedented totalitarian communism in that country. Private ownership of land was banned, and all land registration records were destroyed. In 1979, Vietnamese forces helped overthrow the Khmer Rouge (although the Khmer Rouge continued to occupy large parts of the country, and the government would not gain full control of the country until 1998). As early as 1989, the government of Cambodia had introduced private ownership for residential and business land parcels as well as possession rights to agricultural lands. The initial re-introduction of private property took the form of a broad-based land redistribution and privatization program. After the system that was introduced for privatization proved to be insecure and exclusive' in practice, the government recognized that land issues had to be re-addressed 'in the name of stabilisation and normalisation. ${ }^{95}$ Accordingly, in 1995, the government of Cambodia - with support from the governments of Finland, France, and Germany — developed and implemented a systematic land registration process. The process was tested for two years and, during

80 Jon Unruh and Harry Turray, FAO, Land Tenure, Food Security and Investment in Postwar Sierra Leone, LSP Working Paper 22 (2006), <ftp://ftp.fao.org/docrep/fao/009/ ah243e/ah243e00.pdf>; and personal communication with Jon Unruh (10 January 2007).

81 McEwen and Nolan, supra note 74 at 17.

82 Unruh, supra note 14 at $25 . \quad{ }^{83}$ Ibid.

84 Mika-Petteri Törhönen and David Palmer, FAO, Land Administration in Post Conflict Cambodia, at 1 (2004), <http://www.fig.net/commission7/geneva_2004/papers/lapca_04_ torhonen_palmer.pdf $>$. 
this piloting stage, approximately 40,000 parcels were registered. ${ }^{86}$ The success of the systematic registration and its popularity among the public provided the foundation for a 2001 law that formally institutionalized the new land registration system throughout the country.

Post-conflict land access, tenure, and reform have many aspects in common with more general (peacetime) land issues. Experience, however, shows that the post-conflict context can complicate these processes and dynamics. There are more institutions involved, particularly external organizations, such as UN relief, development, and peacekeeping agencies; bilateral agencies; and non-governmental organizations (NGOs). There is much less trust and confidence, both in various social groups and in the government. Post-conflict countries are also characterized by an urgent need to provide for humanitarian needs (including settling and resettling IDPs and refugees), which creates pressure to act quickly even though land reform often takes many years to implement. Experiences with post-conflict land reform highlight the utility of legal pluralism, the interactions between formal and customary tenure, and opportunities to use a micro rule-of-law system for land tenure in transitioning to peace. In fact, the inability to resolve land issues has been cited as the primary cause for conflict relapse. ${ }^{87}$

This growing body of experience attests to the importance of providing secure access to land in post-conflict countries. The FAO has developed significant expertise in assisting post-conflict countries in reforming laws, institutions, and practices to improve access to land. The organization has developed a practical guide - based on what the FAO and its collaborators have identified as 'good practices'-for use by land tenure and administration specialists who are establishing or reforming land tenure systems in post-conflict countries. ${ }^{88}$ The guide identifies:

- key issues of land tenure and its administration that must be addressed during the initial interventions (largely humanitarian in nature) following preliminary assessments;

- key questions to resolve regarding restitution, resettlement, and the establishment of an operational land administration system, following the conclusion of emergency activities, defined as efforts focused on providing humanitarian services and establishing basic governance, usually carried out in the immediate aftermath of conflict, before fullscale mobilization of aid resources has started;

- common issues that may be encountered in monitoring and evaluating the effects of such policies; and

- the roles that land administrators play throughout the process.

86 FAO, supra note 15 (describing this process in detail).

87 See International Development Research Centre, War-Torn Societies Project, <http:// www.idrc.ca/fr/ev-32232-201-1-DO_TOPIC.html>. 
While the FAO guide represents a significant step in collecting lessons learned, the guide is also a first step towards the development of more detailed operational guidance that is suitable for field usage.

(ii) Landmines and de-mining

The presence of landmines and unexploded ordinance (UXO), including cluster munitions, can affect the recovery and stability of post-conflict countries. Not only do they kill and maim, but they also limit or prevent access to key natural resources while highlighting the limitations of the government just as it is trying to re-establish itself. As such, the timely removal of mines and UXO can affect the transition to peace. As many as 500,000 landmines remain in Mozambique, primarily in the provinces of Zambezia and Nampula. These provinces are the most fertile and populous areas of the country, and the mines have rendered large areas of prime agricultural land unusable and uninhabitable for many years. Efforts to remove the mines have been only partially successful, and many of the country's difficulties in recovering from conflict can be traced to the residual landmines. Analysis using geographic information system software has revealed a 'spatial coincidence in mid-Zambezia of mines and land conflict, demobilized combatants and dependents, and dislocatees, revealing an area of significant ongoing contention. ${ }^{89}$ The abandonment of fertile areas due to the presence of landmines has led to overcrowding, over-cultivation, and the degradation of the remaining agricultural areas. Mines have created substantial changes in population, land use, and land tenure patterns that have ignited land conflicts in the two provinces that have historically been responsible for the majority of Mozambican agricultural productivity.

Other post-conflict countries with large numbers of landmines and UXO remaining after armed conflict-including Afghanistan, Angola, Bosnia/ Herzegovina, Cambodia, Ethiopia, Eritrea, Somalia, and Vietnam-share Mozambique's challenges in effectively making a peaceful transition. A staggering 35 percent of arable land in Cambodia is unusable because of landmines, complicating food security for the country. ${ }^{90}$ During the Nicaraguan civil war (1981-9), the Nicaraguan army planted more than 135,000 landmines along the country's northern border with Honduras. The landmines that remain have constrained the use and development of infrastructure, including roads, bridges, power sources, and communications. ${ }^{91}$ The mines

89 D. Jon Unruh et al., The Political Ecology of Recovery from Armed Conflict: The Case of Landmines in Mozambique 22 Political Geography 841 at 851 (2003), <http://www.uwm.edu/ Dept/Geography/faculty\%20pubs/Heynen/Moz_Mines.pdf $>$.

90 Goovaerts et al., supra note 5.

91 Elizabeth Beery Adams, The History of Demining in Nicaragua, Landmines in Latin America, Mine Action Information Center, <http://maic.jmu.edu/Journal/5.2/focus/ nicaragua.htm>. 
have also hindered people's ability to raise cattle, grow agricultural products, and manage land, leading to higher food prices and harming food security..$^{92}$ Accordingly, de-mining was deemed a 'task of utmost importance... which represents an important component in the peace process. ${ }^{93}$ In response to the problems caused by landmines, the government of Nicaragua initiated the first of four intensive stages of de-mining operations as early as 1989, although extensive de-mining activities have extended into the current decade.

The speed and effectiveness with which a post-conflict government addresses the problems of landmines and their impacts can significantly influence post-conflict recovery efforts and peace processes. In a postconflict environment, 'the state-weakened, and of questionable legitimacy for many after a war-is then likely to become the focus of criticism from those experiencing negative outcomes involving attempts to obtain or re-acquire access to land resources and use of infrastructure. ${ }^{94}$ However, scholars have only begun to address the full range of effects of landmines on post-conflict recovery processes.

(iii) Infrastructure to access resources and markets

De-mining land and reforming land tenure and use are often necessary components of encouraging agricultural development in a post-conflict country, but without proper infrastructure the products of agriculture cannot get to market. Poor road conditions can severely constrain the ability of farmers to get agricultural products to market - particularly fruit, flowers, and other products that may generate increased revenues and thus assist in the restoration of local livelihoods. In addition, inadequate infrastructure can limit access to natural resources, affecting the ability of the country to utilize those resources for recovery. The Central African Republic has a long history of cotton production and should have competitive advantages in cotton export. Yet abnormally high transportation costs have prevented the Central African Republic from reaping the full benefits of its productive potential. Conflict in the 1990s damaged an already underdeveloped road infrastructure, while also 'creat[ing] an environment favorable for pirating along the river way. ${ }^{95}$ A country already suffering from structural economic difficulties due to conflict and chronic poverty is thus constrained in its economic development due in part to inadequate transportation infrastructure.

92 Skuce, supra note 53.

93 Adams, supra note 91 (quoting Major Sergio Ugarte of the Nicaraguan Engineer Corps).

94 Unruh et al., supra note 89 at 857.

95 Said Bakhache et al., Assessing Competitiveness after Conflict: The Case of the Central African Republic, International Monetary Fund, Working Paper no. WP/06/303, at 11 (2006), $<$ http://www.imf.org/external/pubs/ft/wp/2006/wp06303.pdf $>$. 
(iv) Water infrastructure

The construction and maintenance of water and sanitation infrastructure is essential in utilizing water for irrigation, energy, household, and industrial purposes. Post-conflict recovery efforts frequently showcase water and sanitation projects as a peace dividend. Infrastructure improvements are among the most visible post-conflict achievements, and thus their failure can easily lead to disenchantment with the peace process. ${ }^{96}$ The collapse of water treatment infrastructure in such places as Basra, Iraq, and Monrovia, Liberia, have undermined peace since the inability of the new post-conflict regime to provide for the most basic of needs is seen as a sign of governmental failure.

Yet, while the lack of infrastructure can inhibit post-conflict development, large-scale infrastructure designed to share natural resources across previously contesting groups can build confidence. The Enguri Arch Dam physically spans Georgia and the breakaway province of Abkhazia, providing hydroelectric power to both areas. The EU has recognized that the continued operation of the dam is a major source of confidence building and has justified allotting funds to rehabilitate the dam on this basis. ${ }^{97}$ Despite frequent problems with power generation, the Enguri Arch has been an opportunity for cooperation between Georgia and Abkhazia. According to Georgian Enguri Dam director Joni Chania, '[w]e have no problems with the Abkhaz here. They even give surplus energy to Georgia. Remember, before the war, we were family. 98

Iraq has also witnessed extensive focus on water infrastructure. While the recent security situation has hampered the effective delivery of water, sanitation, and other basic services in parts of the country - thereby adding to the grievances of local communities - the relative peace and security of the Kurdistan region has enabled reconstruction projects to improve the delivery of consistent and clean water. Approximately US \$204.2 million of a total US $\$ 595$ million in reconstruction funds in the area have been invested in water resources and sanitation projects. ${ }^{99}$ In addition, the Kurdistan regional government has allocated approximately US $\$ 50$ million in 2006 to a water project in Khanaqin and US $\$ 93,000$ for a water project in Naft Khana. ${ }^{100}$

96 Mott McDonald, Provision of Infrastructure in Post Conflict Situations, Department for International Development (2005), <http://rru.worldbank.org/Documents/PapersLinks/ 6484.pdf $>$.

97 Ibid. at 13 .

98 Paul Rimple, A Region in the Dark, Georgia: Revolution in the Regions, EurasiaNet, $<$ http://www.eurasianet.org/georgia/samegrelo/story.html $>$.

99 US Department of State, Regional Reconstruction Team in the Iraqi Kurdistan Region Fact Sheet, <http://www.state.gov/documents/organization/79901.pdf>.

100 Iraqi Kurdistan Government to Implement 50M Dollar Project in Khanaqin, BBC Global News, 28 December 2006 (on file at Environmental Law Institute). 


\section{Disarmament, Demobilization, and Reintegration (DDR)}

In many post-conflict countries, the lack of productive livelihood opportunities for decommissioned armed forces leads to hardship, frustration, and idleness - factors that render former soldiers susceptible to recruitment by militias, rebel groups, or criminal organizations. ${ }^{101}$ Accordingly, disarming, demobilizing, and reintegrating former combatants are usually top priorities. Proper natural resource management can contribute to post-conflict stability by providing employment opportunities - for example, through agriculture, forestry, fisheries, mining, and so on - to decommissioned combatants who might otherwise constitute a destabilizing force. Bolstering the employment of ex-combatants through natural resource management has been implemented with some success in Afghanistan and Mozambique, among other countries.

Afghanistan's US \$141 million New Beginnings Programme (NBP) was a disarmament, demobilization, and reintegration initiative administered by the United Nations Development Program with primary funding from Japan. The NBP sought to facilitate the transition to peace by reintegrating decommissioned armed forces into society, and natural resource management - and particularly agriculture - has been a dominant component of the effort to disarm, demobilize, and reintegrate more than 60,000 former troops. ${ }^{102}$

Over the life of the project, the NBP reintegrated 43 percent of the former officers and soldiers of the Afghan military forces - 23,940 people - providing them with agricultural packages comprising seeds, fertilizer, tools, and training. ${ }^{103}$ By supplying these former troops with the means by which to earn a livelihood, the NBP encouraged Afghanistan's transition from fighting to farming. The work of an additional 843 decommissioned troops trained by the NBP and employed in de-mining activities complemented these efforts by putting previously unusable land into production, thereby assuaging some of the pressure on the country's limited base of arable agricultural land. 104

In Mozambique, the demobilization and reintegration of a large number of military personnel was critical to the successful transition to peace. ${ }^{105}$ To avoid a sudden influx into private society of unemployed and armed

101 Goovaerts et al., supra note 5.

102 UN Development Programme (UNDP), Afghanistan's New Beginnings Programme Fact Sheet, (2007), <http://www.undpanbp.org/Overview/factsheet.htm>. $\quad 103$ Ibid

104 Adam Pain and Sue Lautze, Addressing Livelihoods in Afghanistan, Afghanistan Research and Evaluation Unit, Issue Paper Series (2002), <http://www.areu.org.af/index. php?option=com_docmanandtask=doc_viewandgid=264>; UNDP, supra note 102; Wily, supra note 69 at $1 \overline{1}$.

105 C. Alden, Making Old Soldiers Fade Away: Lessons from the Reintegration of Demobilized Soldiers in Mozambique 33(3) Security Dialogue 341 (2001). 
ex-combatants, Mozambique's National Directorate of Forestry and Wildlife recruited demobilized soldiers to become game scouts and wardens in protected areas such as the Gorongosa National Park.106 The soldiers' bush skills-tracking, handling firearms, and self-sufficiency-aligned well with those skills needed to control illegal hunting. Such employment provided livelihoods for many demobilized soldiers, who, lacking land or other income sources, might have otherwise resorted to banditry, which would then have threatened the security and fragile post-war stability. The employment of former combatants in the national park has had ancillary long-term benefits within Mozambique's government. Building on relationships that were cultivated through the demobilization process, Mozambique's Ministry of Defense and Ministry of Tourism later entered into a formal agreement by which the army would assist in policing the country's national parks. ${ }^{107}$

\section{Strengthening Governance and Addressing Past Injustices}

In addition to preventing a return to conflict, helping to meet basic needs, and employing decommissioned armed forces, effective natural resource management can strengthen governance and justice in post-conflict countries. Since reforms in the laws, institutions, and practices that govern natural resource directly affect the needs of many people, management changes can be far-reaching in their direct effects and can also serve as high-profile models to catalyze and inform other governance reforms. In addition, to the extent that natural resources were abused during conflict-for example, sold to purchase weapons - formally addressing past injustices in the distribution and use of resources can help to move away from past grievances.

The Liberia Forest Concession Review, a review of forest concessions conducted by a joint Liberian/international Forest Concession Review Committee, appointed by the Liberian government, 'provide[s] a model of internationalized action adaptable to the reform of other sectors and the elimination of sources of conflict. '108 Reaching beyond the forest sector, the review called for the creation of a formal historical record of illegality and mismanagement that highlights the compounding effects of prolonged lawlessness and civil disturbance, with the goal of redressing and preventing the repetition of past injustices. This review has been at the forefront of

106 John Hatton, Mia Couto, and Judy Oglethorpe, Biodiversity and War: A Case Study from Mozambique, World Wildlife Fund, Biodiversity Support Program (2001), <http://www. worldwildlife.org/bsp/publications/africa/146/Mozambique.pdf $>$.

107 Personal communication with Alda Saloma, Centro Terra Viva-Estudos e Advocacia Ambiental (Mozambique), 13 December 2006.

108 K.W. James Rochow et al., The Liberia Forest Concession Review: Lessons for Resource Management and the Restoration of the Rule of Law 3(1) J. Peacekeeping \& Development 89 at 5 (2006). 
efforts to reintroduce the rule of law in post-conflict Liberia, providing the groundwork for Liberia's National Forestry Reform Law and Executive Order no. 1. The framework of the forest concession review has already been used as the model for the review of other natural resource concessions in Liberia - such as rubber, oil, and gas - and it 'could be used as a precedent for other restabilizing countries. ${ }^{\text {'109 }}$ One expert involved in the process has made the following observation:

The mimesis of the rule of law $\left[{ }^{110}\right]$ incorporated in the review has helped to demonstrate the kinds of legal and administrative requirements and transparent procedures increasingly demanded by advocates in Liberia and other countries as necessary to secure a law-based society. ${ }^{111}$

A second step towards rebuilding the forest sector was the adoption of the National Forestry Reform Law of 2006. The new law provides a foundation for increased transparency, accountability, and democracy. ${ }^{112}$ The reform of the forestry sector has the potential for establishing models for community participation, transparent governance, and sustainable resource use in Liberia, while helping to rebuild people's confidence in government institutions. For example, draft regulations to implement the National Forestry Reform Act went through several notice-and-comment procedures, which was the first time that Liberia had undertaken public notice and comment when developing regulations in any sector.

Liberia's National Forestry Reform Law demonstrates the potential of governance reform in the natural resource sector to explicitly remedy past injustice. Historically, local communities have received few benefits from the logging companies that operate in their midst. Indeed, the detrimental effects of forest mismanagement in Liberia has gone beyond inequity in benefit sharing to actual harm:

[T]imber companies used private militias to gain control over local populations, discourage protests, and encroach on communal lands. Timber militias, along with the military and the police, intimidate local communities, destroy and steal goods, and seize farms and forest land for companies. ${ }^{113}$

The new law engages rural communities that have traditionally been marginalized from the forest decision-making process and provides them with

109 Ibid:; K.W. James Rochow, personal communication to Environmental Law Institute, 18 May 2007.

110 The review process was structured to reinforce its fundamental goal of restoring the rule of law. It was therefore conducted in a transparent manner, with its methodology widely publicized and the entire process structured to adhere to sound legal and administrative process. Rochow et al., supra note 108 at 2.

111 Ibid. at 5

112 Liberian President Ellen Johnson-Sirleaf Signs National Forestry Reform Law of 2006, Environmental Law Institute Press Release (5 October 2006), <http://www2.eli.org/pressdetail. cfm?ID $=150>$. 
the benefits of forest use. ${ }^{114}$ The law sets forth a new governance framework that relies on public access to information, public participation in decision making, transparency, improved reporting mechanisms, and the sound management of resources.

To address Liberia's historic inequities, the new forestry law prescribes two mechanisms for distributing benefits from commercial logging to rural communities. Under the law, every company in possession of a logging concession contract for an area between 50,000 and 400,000 hectares must enter into a social contract with the surrounding community. Under the contract, the company is responsible for pooling a percentage of its stumpage fees (the fee paid by companies or individuals for the right to harvest timber) into a dedicated trust for the exclusive use of that community. A tax redistribution mechanism also collects 30 percent of the total land rental fees paid by the logging companies into a national trust from which affected communities may draw for community improvement projects. In reforming the governance of the timber sector, Liberia's new forestry law promises to transform the possession of natural resources from a curse into a source of prosperity for local communities. Moreover, the reform of the forestry sector, which is important not only to the national treasury but also to the economic security of many communities, offers enormous potential as a model for the improved governance of many other sectors in post-conflict Liberia. Finally, the precise rights and roles of communities are likely to be further clarified through a law on community forestry that is under development, which will complement the 2006 National Forestry Reform Law.

Afghanistan's Environment Act provides another example of a legal tool for natural resource management that may trigger broader governance reform. ${ }^{115}$ The new law was passed in December 2005 and is driven principally by the recognition that environmental degradation in Afghanistan is contributing to a general sense of insecurity as subsistence farmers, who have been displaced by desertification and crop failure, have turned to illicit activities including violence and poppy cultivation. The law constructs new frameworks for managing natural resource conservation and biodiversity, drinking water quality, pollution control, and environmental education. Additionally, the new law has the potential to spur institutional reform in other sectors by clarifying administrative roles at the national level as well as coordination with provincial authorities. ${ }^{116}$

One of the primary impediments to establishing a lasting peace in Iraq is reaching a solution on the allocation of oil rights and revenues. In

114 What the People Say: A Contribution of Liberians' Voices and Ideas about Timber Exploitation in Liberia, Search for Common Ground (2005), <http://www.fao.org/forestry/ site/29659/en/page.jsp>.

115 Environment Act, 18 December 2005, <http://www.aisa.org.af/Downloads/laws/873Env.law.pdf $>$. 
March 2007, Iraq's cabinet endorsed a draft oil and gas law that was 'seen as necessary to a political settlement of the nearly four-year-old-war.'117 The draft law seeks to be 'a compromise between Sunnis, Shi'a, and Kurds [that provides]... a foundation stone for building the state. ${ }^{118}$ It would require petroleum revenues to be distributed to the governorates or regions according to their population, and it authorizes regional governments and oil companies to pursue contracts with foreign companies for the development and exploration of oil fields.

Iraq's new federal law is modeled after the Kurdistan Region Petroleum Act. ${ }^{119}$ The earlier act attempts to bring economic, political, and social stability by requiring petroleum contractors to 'demonstrate a record of compliance with principles of good corporate citizenship, and a commitment to the Ten Principles of the Global Compact,' as well as by 'attracting private investors with competitive production sharing agreements.' ${ }^{\prime 20}$ These acts implement a provision within the Constitution of Iraq that seeks to compensate past injustices by distributing petroleum revenues 'based on population and the degree of damage done by the previous regime to parts of the country. ${ }^{\text {'21 }}$ Ashti Abdullah Hawrami, the Kurdistan regional government's minister for natural resources, is optimistic that a 'larger... pool of revenues' and clear provisions detailing revenue sharing will ultimately 'benefit all... Iraqi people.' According to Khalid Salih, the Kurdistan regional government's official spokesman, 'the whole point of regions and governorates sharing revenues from natural resources is that it will prevent conflicts in the future.' ${ }^{\prime 22}$ Notwithstanding the high priority on reaching a politicaland legal - accord on sharing oil revenues, it was still unresolved as of April 2009. ${ }^{123}$

In most post-conflict societies, natural resources play a significant role in the post-conflict peace-building process by providing opportunities for livelihoods (including DDR), meeting essential services, and peace dividends. In many instances, land, high-value natural resources such as diamonds and oil, and other resources have been subject to abuse and corruption before and during the conflict as well as after the conflict. Accordingly, reform of the natural resource sector can provide an opportunity to demonstrate

117 Iraqis Agree Oil Deal to Spread the Wealth, CNN News Article, 26 February 2007 $<$ http://www.aina.org/news/2007022616953.jsp>. 118 Ibid.

119 Oil and Gas Law of the Kurdistan Region - Iraq, Law no. (22)-2007 < http://www.krg.org/ uploads/documents/Kurdistan $\% 20$ Oil $\% 20$ and $\% 20$ Gas $\% 20$ Law $\% 20$ English__2007_09_06_ h14m0s42.pdf>; see also Kathleen Ridolfo, Draft Oil Law Aims to Please All Sides, Radio Free Europe/Radio Liberty, 2 March 2007, <http://www.rferl.org/content/Article/1075033.html>.

${ }^{120}$ Kurdistan Region to Require Global Compact Compliance from Petroleum Contractors 2006(4) Compact Quarterly (2006), <http://www.enewsbuilder.net/globalcompact/e_article 000684867.cfm? $=\mathrm{b} 11,0, \mathrm{w}>$.

121 Ibid.

122 KRG Natural Resources Minister: Draft Petroleum Act a Win-Win for All Iraq, Iraq Updates, 21 September 2006, <http://www.iraqupdates.com/p_articles.php/article/10635>.

123 See Iraq Oil and Gas Network, <http://www.iraqog.com/>. 
the structural and practical benefits of peace to the people, while increasing confidence in government institutions. Reforms in natural resource sectors - and the public confidence engendered by the reforms - can support and lead to reforms in other sectors where benefits are less obvious to the population, such as taxation.

\section{LESSONS LEARNED}

The range of experiences over the past thirty years and more demonstrate that decisions and actions regarding natural resources can both unite and divide post-conflict societies. Ineffective or inequitable natural resource management can reignite conflict by aggravating and perpetuating grievances. Conversely, shared management, equitable distribution, and effective legislation can foster cooperation among formerly antagonistic groups. Natural resources can also at times provide quick wins that highlight the value of peace for the public.

Every country or region emerging from conflict has its unique history and distinct political, economic, social, and natural environment, and such factors determine the applicability, prioritization, and efficacy of any particular form of natural resource management as a peace-building approach. A conflict borne of land scarcity will not necessarily respond to the same management strategies as a dispute motivated by the historically corrupt distribution of diamond export revenues or a political conflict that has caused serious environmental harm. Still, there are a number of lessons that can be learned as well as principles and concerns that have transcended the particular contextual elements of the various post-conflict countries and the particularities of each natural resource. These principles and lessons generally influence the effectiveness of post-conflict peace building and natural resource management:

- The challenges of post-conflict economies. Post-conflict economic systems are extremely complex and fragmented in nature, incorporating elements of the formal economy as well as parallel aid and illegal and livelihood economies. This fragmentation affects social structures, shrinking the circle of potential trusted economic partners. In terms of natural resources, this situation typically leads to more extractive practices for short-term gain and undermines efforts for long-term sustainable natural resource management and sound environmental policy.

- Policy disconnects. There is often a disconnect between articulated policies and on-the-ground action in post-conflict natural resource management. This applies both to international organizations working in post-conflict countries and to the countries themselves. Such a situation is due to various factors, including the lower priority that 
international organizations often place on natural resource issues during post-conflict peace building and recovery.

- Importance of community engagement. Engaging local communities is essential for ensuring that policies, management decisions, and initiatives are appropriate to the local context and that there is political and popular support. Natural resources and environmental issues can provide a context for post-conflict communities to find common ground, cooperate, coordinate, and build trust. This is especially true of water management, in which a single source is often shared by former adversaries so there is a common need and shared interest that can provide incentive to cooperate.

- Monitoring and third-party oversight. Due to the limited capacity of post-conflict governments (especially transition governments), the monitoring of post-conflict natural resource management is often lacking. Third-party oversight by UN agencies, outside states, and/or NGOs is often necessary, at least during the transition to peace as governmental capacity is built.

- Financing. In post-conflict peace building and recovery, limited resources are available for environmental and natural resource initiatives. To some extent, natural resource management can be self-funding through usage fees and excise taxes. However, environmental administrations often are regulatory in nature and do not generate funds for their activities. Funding mechanisms for new policies and programs should be considered up front.

- Incremental approaches. Success can often be better achieved through a series of small, incremental steps rather than through a single act of sweeping reform.

In addition to these general lessons, experience in post-conflict peace building highlights some key opportunities for further study and investigation. These opportunities include refining peace-building guidance and doctrine to more effectively account for natural resource management, addressing the conflicting time frames used by the environmental and security community, and clarifying whether and how international environmental law-and particularly multilateral environmental agreements (MEAs) - apply during post-conflict recovery and peace building.

1. Peace-building Guidance and Doctrine Do Not Effectively Account for Natural Resource Management

Post-conflict natural resource management frequently can affect-for better or worse - the socio-economic, governance, security, and justice and reconciliation dimensions of peace building. Significantly, however, most conceptual and operational frameworks do not currently account for the 
environment in an effective way. For example, the US Institute of Peace and the US Army Peacekeeping and Stabilization Operations Institute have developed Guiding Principles for Peace Operations. ${ }^{124}$ These guiding principles (in draft form, as of March 2009) were developed through a comprehensive review of numerous operational guidelines, handbooks, and other documents prepared by multilateral, bilateral, and non-governmental organizations working in post-conflict contexts, as well as extensive consultation in the United States and internationally. Attempting to synthesize these perspectives, the guiding principles frame post-conflict activity within five themes - rule of law, safe and secure environment, social well-being, stable governance, and sustainable economy-each subdivided into four or five principles as well as some cross-cutting principles. However, none of the principles explicitly addresses natural resources or the environment. This is not to say that the guiding principles ignore natural resources or the environment but, rather, that they are not systematically acknowledged as a common means or the context for achieving the stated post-conflict objectives. Since natural resources are not explicitly provided for in formal doctrine or guidance documents, they are not appropriately programmed.

This lack of explicit and detailed consideration of natural resources in the guiding principles reflects similar gaps in other institutional doctrine and guidance documents shaping post-conflict peace building and recovery. There is an urgent need for institutional doctrine and operational guidance developed by all actors in the post-conflict peace-building and recovery field in order to acknowledge and account for the potentially significant role of natural resources. With its mandate to identify ways of improving peace building, the UN Peacebuilding Commission constitutes a means for injecting consideration of natural resources into UN post-conflict peacebuilding efforts.

\section{Post-Conflict Natural Resource Management Is Different}

It is important for environmental experts and professionals to recognize that post-conflict natural resource management is different from peacetime natural resource management. Institutional capacity is weakened, and governmental authority is frequently non-existent. Political priorities are focused on recovery and maintaining the peace, not on sustainable development. The time horizons tend to be shorter, and decisions are made more quickly. The approaches and principles that normally apply in sustainably managing natural resources and the environment frequently are infeasible — and maybe inappropriate - in a post-conflict setting. This is not to say that sustainability is irrelevant. However, expedited processes may be necessary, for example, for environmental impact assessment. Similarly,

\footnotetext{
124 See Beth Cole, Guiding Principles for Peace Operations < http://www.usip.org/baton2009/ extras/cole.pdf $>$.
} 
temporarily unsustainable use of a resource may be necessary in a transition to a sustainable peace.

To be clear, effective natural resource management is frequently important in post-conflict peace building. Frequently, it is in the overarching service of objectives other than environmental sustainability or preservation (namely peace, humanitarian relief, and recovery). Moreover, the post-conflict constraints, demands, and priorities mean that it is often necessary to adapt natural resource management techniques that would otherwise be used in peacetime.

\section{Time Frames Often Conflict}

There is a tendency when dealing with large-scale environmental issues to view temporal priority in moral terms. Environmental actors are concerned with long-term threats with catastrophic potential on a global scale and, thus, are fundamentally drawn to a long-term perspective. Yet by their very nature, post-conflict situations are replete with short-term threats of dire significance. For the typical professional working in postconflict societies, who is constantly aware of the risk of conflict relapse, it is necessary to focus on the immediate needs of the post-conflict community. This clash in temporal priority between environmental and postconflict interests can dissuade the proper use of post-conflict natural resource management:

[Post-conflict p]riorities typically lie in meeting humanitarian needs, demobilization, disarmament and reintegration, supporting elections, restoring order and the rule of law, and opening the economy to foreign investment. The environment and natural resources are often framed as issues to be addressed at a later stage. ${ }^{125}$

Unfortunately, postponing any productive action on natural resource and environment matters does not stop natural resource management choices from being made, it only stops them from being made with proper attention and deliberation. By separating the temporal scales of peace building and environmental action, countries can become locked into 'unsustainable trajectories of recovery that may undermine long-term peace and stability. ${ }^{\text {'26 }}$

One way to resolve this dilemma is to educate the post-conflict community. Education is necessary to raise awareness not only of the potential longterm environmental harm that can be caused by a lack of early attention to environmental concerns but also of the potential for poor management to generate untenable social, economic, and political situations that could lead to conflict recurrence. The short-term goal of post-conflict action is to achieve long-term peace, and education can reduce the likelihood that inappropriate natural resource decisions will undermine the prospects of long-term peace. 
Yet, at the same time, environmental interests may need to account for cases where environmental sacrifice for the sake of peace is in the longterm best interests of all. Japanese coal production following the Second World War illustrates the complexity of the dilemma since a seemingly short-sighted natural resource decision (coal mining was not sustainable or necessarily economical in post-war Japan) made a direct contribution to long-term peace and development. Following the end of the Second World War, the occupying authority poured massive subsidies into Japanese coal mining and steel production. ${ }^{127}$ From the perspective of sustainable natural resource development, the encouragement of Japanese coal mining was a major error. Even ignoring the detrimental environmental effects, the coal reserves of Japan were not sufficiently large or accessible to form the basis of a long-term economic program. However, in the post-war period, with world coal production in disarray, domestic production was essential to foster the Japanese steel industry, and, by developing it, the Japanese heavy industry and economy were revived. Moreover, the labour-intensive coal industry provided stable jobs (for a few years) for former combatants, facilitating disarmament, demobilization, and reintegration. In time, inefficiently produced coal was superseded by cheaper imported energy sources. ${ }^{128}$ A short-term encouragement of unsustainable natural resource development fostered the growth of industries with long-term potential.

\section{Uncertainty over the Role of MEAs}

Despite the rapid growth of MEAs in recent decades-UNEP estimates that there are more than 700 MEAs $^{129}$ - their applicability and relevance during conflict and post-conflict periods remain ambiguous. In 2008, the Drafting Committee of the International Law Commission (ILC) provisionally adopted draft articles on the effects of armed conflicts on treaties, including MEAs. ${ }^{130}$ The ILC has concluded that treaties may continue to apply during armed conflict. The potential application of MEAs during post-conflict peace building and recovery is not straightforward. From a legal perspective, there would appear to be little doubt that MEAs should

127 Bernard Elbaum, A Long, Contingent Path to Comparative Advantage: Industrial Policy and the Japanese Iron and Steel Industry, 1900-1973, Department of Economics, University of California, Santa Cruz, Paper no. 629 (2006), <http://repositories.cdlib.org/cgi/viewcontent.c gi? article $=1071$ andcontext $=$ ucscecon $>$.

128 Yoshito Yoshimura, Closure of Japan's Last Large-Scale Coal Mine, IIST World Forum, 15 March 2002, <http://www.iist.or.jp/wf/magazine/0067/0067_E.html>.

129 UNEP, Manual on Compliance with and Enforcement of Multilateral Environmental Agreements, at 29 (2006).

130 Effects of Armed Conflicts on Treaties, Doc. A/CN.4/L.727/Rev.1 (6 June 2008) <http:// daccessdds.un.org/doc/UNDOC/LTD/G08/616/92/PDF/G0861692.pdf?OpenElement> (provisionally adopting the text of most draft articles developed by the International Law Commission); Effects of Armed Conflicts on Treaties, Doc. A/CN.4/L.727/Rev.1/Add.1 (6 June 2008), <http://daccessdds.un.org/doc/UNDOC/LTD/G08/620/70/PDF/G0862070.pdf? OpenElement $>$ (addendum on draft Articles 5 and 13). 
apply during the post-conflict period. By definition, it is after hostilities have ceased that peacetime law - including peacetime international law_-should resume in full. However, there are many practical challenges to applying international environmental law during the post-conflict period. The priorities of the post-conflict government and the international community are on peace building and recovery. So, frequently, there is not significant political will for enforcement domestically or from external donors. Capacity is significantly limited, and whatever institutional and financial resources are available are focused on other issues. The time horizon tends to be focused on the most immediate tasks at hand.

Yet beyond issues of capacity, it is unclear precisely how MEAs should apply in post-conflict settings where rapid and significant redevelopment may be necessary (or perceived to be necessary) in order to avoid conflict recurrence. Certain agreements may impose direct limitations on rapid redevelopment - for example, limitations on greenhouse gas emissions under the Kyoto Protocol or the next climate regime; ${ }^{131}$ requirements for environmental impact assessments (under the Convention on Environmental Impact Assessment in a Transboundary Context or other regional instruments); ${ }^{132}$ and management of hazardous waste from the conflict. If the post-conflict period was brief - say, on the order of a few months - such diversion from MEA requirements might be forgiven. Yet post-conflict recovery and peace building can take many years, and it is far from clear when the environmental interest codified in any given MEA ought to regain precedence over environmentally unsustainable development for the sake of immediate peace.

Despite the challenges, international environmental law is relevant to postconflict peace building and recovery. It provides common, internationally agreed upon frameworks for addressing a range of environmental issuesfrom biodiversity to fisheries to water management to management of chemicals and hazardous wastes - that post-conflict countries face. Thus, the UN 'Environmental Policy and Guidelines for UN Field Missions' adopted in 2009 would require UN peacekeepers to respect-as constituting minimum international environmental standards - the provisions of relevant MEAs. ${ }^{133}$ Under the new policy, UN peacekeepers would integrate MEAs into their operations. Such an undertaking would help to ensure consistent

131 Such restrictions would only apply to the extent that the country's emissions are governed: most post-conflict countries are developing countries (Annex II) and do not currently have any limitations on emissions under the Kyoto Protocol, 37 I.L.M. 32 (1998).

132 Convention on Environmental Impact Assessment in a Transboundary Context, 30 I.L.M. 800 (1991).

133 UN Department of Peacekeeping Operations and Department of Field Support, Ref. 2009.6, Environmental Policy for UN Field Missions, 2009; UN Department of Peacekeeping Operations and Department of Field Support, Environmental Guidelines for UN Field Missions, 2009. 
practice among peacekeeping and peace-building operations, reducing the environmental footprint of peace operations and empowering the United Nations to lead by example.

In the post-conflict rebuilding process, MEAs can provide post-conflict countries with an opportunity to re-engage with the international community. For example, Afghanistan has been at war for more than a generation, during which time many MEAs have been negotiated and entered into force. Following the 2001 war, Afghanistan became party to the 1992 Convention on Biological Diversity (in 2002), the 1992 UN Framework Convention on Climate Change (in 2002), and the ozone agreements (in 2004) (including the 1987 Vienna Convention for the Protection of the Ozone Layer, the 1989 Montreal Protocol on Substances That Deplete the Ozone Layer, and the London, Copenhagen, Montreal, and Beijing Amendments). Similarly, Iraq-which had been at war and under UN sanctions since the late 1980 s - acceded to the ozone agreements in 2008..$^{134}$

MEAs can also help to mobilize resources. For example, the Convention Concerning the Protection of the World Cultural and Natural Heritage (World Heritage Convention), which creates the network of world heritage sites, provides for the creation of a 'List of World Heritage in Danger.' This list includes world heritage sites that are threatened, inter alia, by armed conflict. ${ }^{135}$ While not expressly addressing post-conflict situations, many of the threats found in post-conflict countries could warrant listing. Inclusion on the list compels the UN Educational, Scientific, and Cultural Organization (UNESCO) to take a coordinating and funding role in preserving specific areas of cultural or natural heritage importance. Such a listing was essential in the restoration of the Croatian city of Old Dubrovnik following conflict in the 1990s. ${ }^{136}$ Five national parks in the Democratic Republic of Congo are included on the World Heritage List, and all five are considered to be in danger. Since 2000, UNESCO has coordinated a program to preserve biodiversity in this region. With over US $\$ 4$ million in funds, primarily drawn from the United Nations Foundation, the program has conducted satellite monitoring of gorilla habitat, provided monetary and equipment support

\footnotetext{
134 Convention on Biological Diversity, 31 I.L.M. 818 (1992); UN Framework Convention on Climate Change, 31 I.L.M. 849 (1992); Vienna Convention for the Protection of the Ozone Layer, <http://sedac.ciesin.org/pidb/texts-menu.html>; Montreal Protocol on Substances That Deplete the Ozone Layer, 26 I.L.M. 1550 (1987); 32 I.L.M. 874 (1993); and Adjustments and Amendment to the Montreal Protocol on Substances that Deplete the Ozone Layer (London Amendment, 30 I.L.M. 537 (1991); Copenhagen Amendment, 32 I.L.M. 874 (1993); Montreal Amendment, <http:www.unep.ch/ozone/>; Beijing Amendment (1999), <http:// untreaty.un.org/English/TreatyEvent2002/Texts/English/Beijin_15.pdf>.

135 Convention Concerning the Protection of the World Cultural and Natural Heritage, 11 I.L.M. 1358 (1972) at 11.4.

136 Maja Nodari, Dubrovnik Reborn, UNESCO Courier, February 2000, <http://www. unesco.org/courier/2000_02/uk/pdf/00_02_40.pdf >.
} 
to beleaguered park rangers, and conducted community outreach. ${ }^{137}$ While the program has had success under post-conflict conditions, the actual recurrence of conflict has threatened much of the progress made, exemplifying how post-conflict successes can be undone or threatened by the larger failure to maintain peace. ${ }^{138}$

\section{CONCLUSIONS AND RECOMMENDATIONS}

Experience shows that natural resources frequently can be, and have been, important for post-conflict peace building and recovery. Natural resource management can affect the success or failure of many key aspects of peace building, including the negotiation of a peace agreement; disarmament, demobilization, and reintegration; meeting essential needs of refugees and IDPs; rebuilding the economy; strengthening governance; providing 'quick wins' to illustrate the benefits of peace; and building confidence and trust. In light of the broad range of experiences over the past three decades, the question of 'why' to consider natural resources in a post-conflict context is quickly evolving into the question of 'how.'

However, there is as yet a broad failure of law, policy, and institutions to effectively account for natural resources in post-conflict peace building. International environmental law-including MEAs-generally does not consider whether or how it applies in the post-conflict setting. Multilateral and bilateral policies and operational guidance generally fail to address the opportunities or risks of natural resources in post-conflict peace building and recovery. For example, despite its various experiences with utilizing natural resources to facilitate the disarmament, demobilization, and reintegration of former combatants, the UN Operational Guide on DDR does not address natural resources. ${ }^{139}$ One promising mechanism for creating a coherent post-conflict vision that has shown receptivity is the UN Peacebuilding Commission. This commission is an advisory body, albeit to the UN Security Council; as such, even if the commission were to prioritize natural resources it would still be necessary to convince the UN Security Council as well as other components of the UN system to follow through on its recommendations.

Finally, there is no effective conceptual framework (or frameworks) for analyzing, explaining, or understanding the role of natural resources

137 Biodiversity Conservation in Regions of Armed Conflict: Conserving World Heritage Sites in the Democratic Republic of Congo, UN Educational, Scientific, and Cultural Organization (UNESCO)/United Nations Foundation Biodiversity Partnerships Brochure, <http://portal. unesco.org/culture/en/files/12097/10618379711DRC.pdf/DRC.pdf>.

138 UNESCO, Garamba National Park (DRC) Attacked by LRA Rebels, 7 January 2009, $<$ http://whc.unesco.org/en/news/479>.

139 Operational Guide to the Integrated Disarmament, Demobilization and Reintegration Standards, UN Inter-Agency Working Group on DDR (2006). 
in post-conflict peace building. There is some scholarly literature, but it tends to be isolated. In contrast with the well-established literature on the environmental consequences of war (starting in the early 1970s), environmental security (taking off in the 1990s), and environmental dispute management and resolution, there is no clearly defined body of scholarship or set of conceptual frameworks on post-conflict natural resource management and peace building.

In order to improve peace building through more effective and appropriate natural resource management, the international community needs to undertake a range of research as well as the development of guidance and policy, capacity building, and technical assistance. The first step is to examine experiences, compare approaches, and identify lessons learned. This is underway through the global initiative described earlier in this article. ${ }^{140}$ Further scholarship will be necessary, as new approaches are tested on the ground, new analytic tools are brought to bear, and further results become available. It is necessary for the academic and research communities to discuss the issues within a conceptual framework that is consistent with how implementing agencies and other people in the field view, construct, and undertake post-conflict interventions. ${ }^{141}$ Ongoing explorations by international organizations to add provisions to existing guidelines or to create new modules within existing structures are welcome signs of progress. Yet so long as the incorporation of natural resource management into larger post-conflict structures is conducted in an ad hoc manner, funding, staffing, and time will be squandered, as the same lessons are learned and relearned in different post-conflict contexts and organizations.

Once there is a body of lessons learned based on experience and empirical analysis, this information can inform the development and reform of institutions and operational policies. The UN Peacebuilding Commission is uniquely positioned to highlight such lessons learned and make recommendations to the UN Security Council for improving UN operations. In some instances, it will be possible to add a module to existing guidelines (for example, the UN Operational Guide on DDR). For other issues, new guidelines will be necessary. The European Union and the United Nations have embarked upon a partnership on conflict and natural resources, entitled

\footnotetext{
140 See note 18 and accompanying text in this article.

141 'The lack of an overall framework to deal with land issues [in the post-conflict setting of Southern Kordofan in Sudan] is starkly apparent. Killings and injuries related to land conflict are the single largest risk to returnees as well as to local communities, yet this does not seem to have been given adequate attention or analysis within UN reintegration efforts.' Sara Pantuliano, Margie Buchanan-Smith, and Paul Murphy, The Long Road Home: Opportunities and Obstacles to the Reintegration of IDPs and Refugees Returning to Southern Sudan and the Three Areas, Department for International Development, Humanitarian Policy Group Commissioned Report, at 10 (2007), <http://www. odi.org.uk/hpg/papers/hpgcommissioned_dfidreintegration.pdf $>$.
} 
'Strengthening Capacities for the Consensual and Sustainable Management of Land and Natural Resources.' One of the outputs of this partnership will be the development of guidance on land, the equitable management of natural wealth, resource scarcity, and post-conflict natural resource management. In addition, bilateral policies, guidance, and operational frameworks will need to be considered since bilateral agencies are significant sources of financial and technical assistance in post-conflict recovery and peace building. Specific guidance may need to be developed for post-conflict land reform, access, management, and dispute resolution (depending on the ultimate scope of the UN land guidance); for the natural resources that fuel conflict by providing a revenue stream for the purchase of weapons (for example, 'conflict diamonds,' timber, oil, rubber, bananas, and so on); and for gender mainstreaming in post-conflict natural resource management, among other issues.

Other measures to strengthen peace building through natural resource management include developing methodologies for mainstreaming environmental issues into conflict analysis as well as tools for mapping, assessing, and setting priority action areas. With the development of these new lessons learned, tools, and resources, it is also necessary to develop the capacity of the various institutions and staff working on post-conflict peace building and recovery as well as of the government staff in post-conflict countries. In many cases, it will be possible to use capacity building and technical assistance to inform and improve ongoing post-conflict processes.

A formal political mandate can significantly raise the profile of natural resource management in peace-building efforts. Such a mandate has to assume the long-term dimension that reflects not just the mainstream of environmental thinking but also the real natural resource management needs of post-conflict regions. This may require moving beyond the sixmonth security mandates normally granted by the UN Security Council. Even though such mandates are often renewed, a six-month window of guaranteed action is far too short to affect the reform in laws, institutions, and ingrained mindsets needed to genuinely improve natural resource management. Natural resource management policy should become an essential, institutionalized, and long-term element of post-conflict policy, with dedicated professionals given the authority to ensure that it is considered in decision making.

Similarly, post-conflict work needs to become more established within natural resource and environmental policy. While a post-conflict world is an attractive vision, future environmental institutions will almost certainly continue to confront conflict and its aftermaths for decades to come. Accordingly, international environmental laws and institutions should be adapted to function in environments where law itself is in a formative or 
reformative stage. Environmental priorities must also be adapted to account for the potential risks of war recurrence for people and for the planet.

Learning processes necessarily entail both successes and failures. Much can be learned from the recent past - what has worked, what has not, why and why not - which can then be translated into operational and institutional reform. To date, natural resource management has not fulfilled its potential for peace building. It has been ad hoc, informal, and far too often ineffective. New laws, policies, and institutional approaches are necessary. However, when undertaken appropriately, natural resource management has the potential to be a cornerstone for more effective and robust postconflict peace-building processes. 